IRISH POETRY: POLITICS, HISTORY, NEGOTIATION 


\section{Irish Poetry: Politics, History, Negotiation}

The Evolving Debate, 1969 to the Present

Steven Matthews 
First published in Great Britain 1997 by

MACMILLAN PRESS LTD

Houndmills, Basingstoke, Hampshire RG21 6XS and London

Companies and representatives throughout the world

A catalogue record for this book is available from the British Library.

ISBN 978-0-333-64336-5 ISBN 978-1-349-25290-9 (eBook)

DOI 10.1007/978-1-349-25290-9

First published in the United States of America 1997 by

ST. MARTIN'S PRESS, INC.,

Scholarly and Reference Division,

175 Fifth Avenue. New York, N.Y. 10010

ISBN 978-0-312-16436-2

Library of Congress Cataloging-in-Publication Data

Matthews, Steven.

Irish poetry : politics, history, negotiation, the evolving

debate, 1969 to the present / Steven Matthews.

p. $\mathrm{cm}$.

Includes bibliographical references and index.

ISBN 978-0-312-16436-2 (cloth)

1. Political poetry, English-Northern Ireland-History and

criticism. 2. Politics and literature-Northem Ireland-

-History-20th century. 3. Literature and history-Northern

Ireland-History-20th century. 4. English poetry-Northern

Ireland-History and criticism. 5. English poetry-Irish authors-

-History and criticism. 6. English poetry-20th century-History

and criticism. 7. Northern Ireland-Intellectual life-20th

century. 8. Northern Ireland-In literature. I. Title.

PR8781.P64M38 1996

$821^{\prime} .914099416-\mathrm{dc} 20$

CIP

() Steven Matthews 1997

All rights reserved. No reproduction, copy or transmission of this publication may be made without written permission.

No paragraph of this publication may be reproduced, copied or transmitted save with written permission or in accordance with the provisions of the Copyright, Designs and Patents Act 1988, or under the terms of any licence permitting limited copying issued by the Copyright Licensing Agency, 90 Tottenham Court Road, London WIP 9HE.

Any person who does any unauthorised act in relation to this publication may be liable to criminal prosecution and civil claims for damages.

The author has asserted his rights to be identified as the author of this work in accordance with the Copyright, Designs and Patents Act 1988.

This book is printed on paper suitable for recycling and made from fully managed and sustained forest sources. Logging, pulping and manufacturing processes are expected to conform to the environmental regulations of the country of origin.

$\begin{array}{llllllllll}10 & 9 & 8 & 7 & 6 & 5 & 4 & 3 & 2 & 1\end{array}$

$\begin{array}{llllllllll}06 & 05 & 04 & 03 & 02 & 01 & 00 & 99 & 98 & 97\end{array}$ 


\section{Contents}

Acknowledgements

vii

1 Introduction: Making History? 1

2 John Hewitt: An Honest Ulsterman's 'Poemosaics' 45

3 Thomas Kinsella's Poetic of Unease 74

4 A Failure to Return: John Montague's The Rough Field 104

5 History Is Only Part of It: Brendan Kennelly's Cromwell 132

6 'Reconciliation Under Duress': The Architecture of Seamus Heaney's Recent Poetry

7 Letters from the Alphabet: Carson's and Muldoon's Contingent Poetics

Notes

Select Bibliography

Index 


\section{Acknowledgements}

My deepest gratitude is to Elleke Boehmer for her wonderful help and support, and for her telling conversation about the book - in short, for making everything possible.

My discussions with Hugh Haughton have always been inspirational and enlivening, and I owe him a great debt. I have also enjoyed important discussions with Shirley Chew, Ian Fairley, Alan Marshall, Alistair Stead, Ashley Taggart, Loreto Todd and John Whale. I would like to thank my Mum, Dad and sister for their backing in some difficult times. I am grateful to the School of English, University of Leeds, for providing me with a travel grant for a research trip to Ireland.

Thanks also to our newly born son Thomas, whose equability created the time to complete this book which would otherwise not have been available.

The author and publishers are grateful to the following for permission to reprint copyright material:

W.H. Auden - Faber \& Faber for extracts from The English Auden and Collected Poems.

Eavan Boland - Carcanet Press for extracts from Selected Poems, Outside History, In a Time of Violence and Object Lessons.

Ciaran Carson - The Gallery Press for extracts from First Language and Letters From the Alphabet.

Brian Friel - Faber \& Faber for an extract from Selected Plays.

Seamus Heaney - Faber \& Faber and Farrar Straus \& Giroux Inc. for extracts from Wintering Out, North, Field Work, Station Island, The Haw Lantern, The Cure at Troy, Seeing Things, Preoccupations, The Government of the Tongue, The Redress of Poetry; The Scholar Press for extracts from The Place of Writing.

John Hewitt - The Blackstaff Press for extracts from Collected Poems and Ancestral Voices. 
viii

Acknowledgements

Thomas Kinsella - Thomas Kinsella for extracts from Poems 1956-1973, New Poems 1973, One and Other Poems, Fifteen Dead, Blood and Family and From Centre City; Carcanet Press for extracts from The Dual Tradition.

Michael Longley - Jonathan Cape for an extract from The Ghost Orchid.

Medbh McGuckian - The Gallery Press for an extract from Captain Lavender.

Paul Muldoon - Faber \& Faber for extracts from Mules, Quoof, Meeting the British, Madoc: A Mystery and The Annals of Chile; Farrar, Straus \& Giroux Inc. for extracts from Madoc and The Annals of Chile; The Gallery Press for extracts from Six Honest Serving Men and The Prince of the Quotidian.

Eiléan Ní Chuilleanáin - The Gallery Press for extracts from The Magdalene Sermon and The Brazen Serpent.

Tom Paulin - Faber \& Faber for an extract from Walking a Line and Minotaur. 